Original Research Paper

\title{
Treatment of Ovarian Inactivity in Mares During the Breeding Season with PMSG/hCG, PMSG or GnRH and the Effect of Treatment on Estradiol and Progesterone Concentrations
}

\author{
${ }^{1,2}$ Mohamed Sabry Medan and ${ }^{2}$ Taher Al-Daek \\ ${ }^{I}$ Department of Theriogenology, Faculty of Veterinary Medicine, Suez Canal University, Ismailia, Egypt \\ ${ }^{2}$ Department of Theriogenology, Faculty of Veterinary Medicine, Omar AL-Mukhtar University, AL-Baida, Libya
}

Article history

Received: 15-07-2014

Revised: 11-09-2014

Accepted: 26-11-2014

Corresponding Author: Mohamed Sabry Medan Department of Theriogenology, Faculty of Veterinary Medicine, Suez Canal University, Ismailia, Egypt Email: medan69@hotmail.com

\begin{abstract}
The objective of the present study was to treat ovarian inactivity in mares during the breeding season by using three protocols. Mares $(n=$ 52) kept under field condition in the Green Mountain area, north of Libya were examined transrectally by ultrasound during the breeding season. They were assigned to have inactive ovaries which was confirmed by measuring serum estradiol and progesterone concentrations. Mares were treated with either PMSG/hCG $(\mathrm{n}=32)$, PMSG alone $(\mathrm{n}=10)$ or GnRH (n $=10$ ). Estrus was detected by stallions and mares in estrus were allowed to be mated two times 2 days apart and examined for pregnancy by ultrasound one month later. The results showed that in the PMSG/hCG group, 19 $(59.4 \%)$ mares out of 32 exhibited estrus, while $6(60 \%)$ and $5(50 \%)$ mares out of 10 exhibited estrus in PMSG and GnRH groups, respectively. Also the results showed that 16 mares $(50.0 \%)$ ovulated in PMSG/hCG group compared with 4 mares $(40.0 \%)$ in GnRH group. However, there was no ovulation in PMSG group. Conception rate was 37.0 and $30.0 \%$ in PMSG/hCG and GnRH groups, respectively. Hormonal analysis showed that estradiol and progesterone concentrations were basal at start of treatment. Thereafter, estradiol concentration increased dramatically during estrus in all treated groups. Moreover, progesterone concentration increased 10 days post-mating in $\mathrm{PMSG} / \mathrm{hCG}$ and $\mathrm{GnRH}$ groups while still low in PMSG group. Finally, we conclude that PMSG/hCG and GnRH can be used to treat ovarian inactivity in mares and induce follicular growth and ovulation. On the other hand, we cannot recommend PMSG alone to treat ovarian inactivity in mares.
\end{abstract}

Keywords: Mares, Ovarian Inactivity, PMSG, hCG, GnRH

\section{Introduction}

Mares are often presented with a history of anestrus during the breeding season. Attempts must be made to stimulate follicular development and ovulation using exogenous hormones. Unfortunately, there are very limited or no data about this subject in the area of the present study. Mares are a seasonally polyestrous with ovulatory activity being related to long days and light. They usually experience reproductive activity between May and October (Nagy et al., 2000). During the breeding season, average estrus cycle length is about 21 to 22 days in length. An estrus during the follicular phase lasts 5-7 days characterized of behavioural signs like increased interest in stallions and proceptive behaviour in response to the sexual attractivity of a stallion (Crowell-Davis, 2007). This is followed by the luteal phase, or diestrus and lasts 14 to 16 days (Aurich, 2001).

Equine FSH (eFSH) has been used to stimulate follicular development in transitional mares and in cycling mares. Administration of eFSH twice daily for 5 to 7 days resulted in ovulation about 7 days after the onset of treatment (Niswender et al., 2004). The disadvantage, however, is the expense of eFSH and the need to administer eFSH twice daily for several days. 
human Chorionic Gonadotropin (hCG) was the first drug used to induce ovulation in the mare. It is a protein hormone and bears LH like activity when used in the mare. The doses range from 1500 IU to 10,000 IU and can be Administered Intravenously (IV), Subcutaneously (SC), or Intramuscular (IM) (Barbacini et al., 2000; Berezowski et al., 2004).

GnRH stimulates the synthesis and release of pituitary gonadotropins, follicle stimulating hormone and luteinizing hormone to control gametogenesis and sex steroid production. Several studies demonstrated that GnRH or its analogues can induce ovulation in seasonal anestrous mares (Palmer et al., 1993; Hyland, 1993).

hCG has been used for several decades for the induction of ovulation in mares. This is an LH-like hormone with a relatively long half-life, which makes it very efficacious in inducing ovulation. Although data are limited, the clinical impression is that hCG works better than the GnRH agonists. The rationale behind this is that hCG works directly on the ovary, whereas GnRH agonists stimulates the pituitary to release LH. Studies have shown that pituitary stores of LH are sometimes limited (Hart et al., 1984) and mares may not respond as well to GnRH agonists as they do to hCG.

Estradiol in the mare is produced from the dominant follicle and feed back to the pituitary resulting in the decrease in FSH and the increase in LH concentrations. The estrogens produced from the ovaries also are responsible for behavioral estrus in the absence of progesterone. One of the key hormones controlling reproductive function in the mare is progesterone. It is the main steroid product of the Corpus Luteum (CL) and its concentration is highest during diestrus and during pregnancy (Squires, 2008). Therefore, estradiol and progesterone can be used as an indicator for ovarian activity.

Ultrasound imaging of the reproductive tract has proved to be important to monitor reproduction in the animals (Samper, 2008). As a result and in accordance with Gastal (2009), some studies have correlated the follicular diameter with the hormonal concentration during the pre-ovulation period in the mares.

\section{Materials and Methods}

\section{Animals and Ultrasound Examination}

A total of 52 mares diagnosed to have smooth inactive ovaries were subjected to this study during the breeding season between 2009 to 2013. The age of animals ranged from 5 to 15 years and their body weight ranged from 350 to $500 \mathrm{~kg}$. The mares were clinically healthy and the external genitalia were normal. Diagnosis was done through case history that mares were anestrus at least 4 months during the breeding season or one year without breeding. Transrectal ultrasound examinations using a either a portable ultrasound scanner (Landwind, C30 Vet) equipped with multi-frequency 5$10 \mathrm{MHz}$, linear-array, rectal transducer or a hand carried digital veterinary ultrasound scanner (EMP-V9 Vet) equipped with linear array rectal transducer was used to confirm diagnosis through the absence of any cyclic functional structure (ovaries without any follicular activity or corpora lutea).

\section{Treatment Schedule}

After diagnosis, animals were divided randomly into three treatment groups according to schedule of treatment as follow:

- PMSG/hCG group: Includes 32 mares injected IM with 5000 IU Pregnant Mare Serum Gonadotopin (PMSG, Gonaser® Hipra Laboratories) and 3000 IU human Chorionic Gonadotropin (hCG, Chorulon ${ }^{\circledR}$ Intervet). PMSG was injected at the time of diagnosis, while hCG was injected during estrus at mating

- PMSG group: Includes 10 mares injected IM with 5000 IU PMSG alone at the time of diagnosis

- GnRH group: Includes 10 mares injected daily with $0.04 \mathrm{mg} \mathrm{GnRH}$ analogue (Buserelin acetate, Fertilin ${ }^{\circledR}$ Provet) for 3 days starting at diagnosis and one injection during estrus at mating

\section{Estrus Detection and Breeding}

After treatment, mares were teased daily with a stallion to detect estrus. After observing estrus signs including urination, winking and lack of resistance of the mare to the stallion, ovarian follicular development was confirmed by transrectal ultrasonography to detect the preovulatory follicles. Mares in estrus were mated two times, two days apart by a fertile stallion.

\section{Ovulation Confirmation and Pregnancy Determination}

Ovulation was confirmed by transrectal ultrasonography 3 days post-mating (Absence of large preovulatory follicles) and an increase in progesterone concentration 10 days post-mating. Also pregnancy was determined by transrectal ultrasonography 30 days post-mating.

\section{Blood Samples and Hormones Measurement}

About $10 \mathrm{~mL}$ of blood samples were collected by venipuncture of the jugular vein of all animals in the examined groups at start of treatment, during estrus and 10 days post-mating. Blood was collected into vacuum tubes not containing anticoagulant. The tubes were centrifuged at $3000 \mathrm{rpm}$ for $15 \mathrm{~min}$ and the sera were aspirated and stored at $-20^{\circ} \mathrm{C}$ until hormonal analysis. 
Table 1. Reproductive performance of anestrous mares after treatment with PMSG/hCG combination, PMSG alone or GnRH

\begin{tabular}{lllll}
\hline Group & $\begin{array}{l}\text { No of anestrous } \\
\text { mares }\end{array}$ & $\begin{array}{l}\text { No of mares } \\
\text { exhibiting estrus }(\%)^{1}\end{array}$ & $\begin{array}{l}\text { No of mares } \\
\text { ovulating }(\%)^{2}\end{array}$ & $\begin{array}{l}\text { No of mares } \\
\text { conceiving }(\%)^{3}\end{array}$ \\
\hline PMSG/hCG & 32 & $19(59.4)^{\mathrm{a}}$ & $16(50.0)^{\mathrm{a}}$ & $12(37.0)^{\mathrm{a}}$ \\
PMSG & 10 & $6(60)^{\mathrm{a}}$ & $0(0.0)^{\mathrm{b}}$ & $0(0.0)^{\mathrm{b}}$ \\
GnRH & 10 & $5(50.0)^{\mathrm{a} *}$ & $4(40.0)^{\mathrm{a}}$ & $3(30.0)^{\mathrm{a}}$ \\
\hline
\end{tabular}

${ }^{\mathrm{ab}}$ Differ significantly in the same column $\mathrm{p}<0.01$

${ }^{1}$ Number of mares that showed estrus within 2 weeks of treatment

${ }^{2}$ Number of mares confirmed ovulating by ultrasound

${ }^{3}$ Number of mares confirmed pregnant by ultrasound

* Signs of estrus is not so clear although mares accepted stallion

Table 2. Serum concentration of progesterone $(\mathrm{ng} / \mathrm{mL})$ in anestrous mares before and after treatment with PMSG/hCG combination, PMSG alone or GnRH

\begin{tabular}{llll}
\hline Group & Before treatment & Mares in estrus & 10 days post-mating \\
\hline PMSG/hCG & $0.29 \pm 0.03$ & $0.39 \pm 0.04$ & $9.47 \pm 0.77$ \\
PMSG & $0.28 \pm 0.04$ & $0.40 \pm 0.06$ & $1.8 \pm 0.37^{*}$ \\
GnRH & $0.33 \pm 0.06$ & $0.52 \pm 0.09$ & $10.5 \pm 0.87$ \\
\hline
\end{tabular}

*Significantly low compared with other groups $\mathrm{p}<0.05$

Table 3. Serum concentration of estradiol- $17 \beta(\mathrm{pg} / \mathrm{mL})$ in anestrous mares before and after treatment with PMSG/hCG combination, PMSG alone or GnRH

\begin{tabular}{llll}
\hline Group & Before treatment & Mares in estrus & 10 days post-mating \\
\hline PMSG/hCG & $5.9 \pm 0.3$ & $45.6 \pm 2.0$ & $8.3 \pm 0.7$ \\
PMSG & $5.2 \pm 0.3$ & $44.8 \pm 2.6$ & $14.2 \pm 2.2^{*}$ \\
GnRH & $5.0 \pm 0.4$ & $38.6 \pm 1.7$ & $6.5 \pm 0.9$ \\
\hline
\end{tabular}

*Significantly high compared with other groups $\mathrm{p}<0.05$

Progesterone was measured by an enzyme immunoassay as described previously (Irvine et al., 1990). Also, estradiol-17 $\beta$ was measured by enzyme immunoassay as described previously (Stabenfeldt et al., 1991).

\section{Statistical Analysis}

The data were analyzed using SPSS software (SPSS, 2011) Chi Square test $\left(X^{2}\right)$ was used to determine the differences in the reproductive performance among treatment groups. Differences were considered to be significant at $\mathrm{p}<0.05$.

Hormonal concentrations were expressed as mean \pm SE (Standard Error). The Analysis of Variance (ANOVA) was used to test the significance of differences between means. Duncan's multiple range test was applied for post hoc comparison. Differences between means were considered to be significant at $\mathrm{p}<0.05$.

\section{Results}

Reproductive performance of treated anestrous mares is shown in Table 1. In the group treated with PMSG/hCG combination, 19 (59.4\%) out of 32 mares showed estrus within two weeks of treatment and ovulation was confirmed in 16 mares $(50.0 \%)$. In the group treated with PMSG, $6(60.0 \%)$ mares out of 10 showed estrus but there was no ovulation. In the group treated with GnRH analogue, 5 mares $(50.0 \%)$ showed estrus and 4 mares (40.0\%) ovulated. The number of mares conceiving was $12(37.0 \%)$ in the group treated with PMSG/hCG and $3(30.0 \%)$ in the group treated with $\mathrm{GnRH}$ analogue. The results showed that there was no ovulation in the group treated with PMSG alone although there was $6(60.0 \%)$ cases out of 10 exhibited estrus (Table 1). In the group treated with GnRH analogue, although the mares accepted stallion and ovulated, signs of estrus was not so clear as other treatment groups.

Serum progesterone was basal in all groups before treatment as shown in Table 2. Also, during estrus there was no significant changes in progesterone concentration compared with that before treatment. On the other hand, there was a highly significant increase in progesterone concentration in PMSG/hCG $(9.4 \pm 0.77 \mathrm{ng} / \mathrm{mL})$ and GnRH $(10.5 \pm 0.87 \mathrm{ng} / \mathrm{mL})$ groups 10 days post-mating. However, progesterone concentration showed a little bit increase in PMSG group. As shown in Table 3, serum concentration of estradiol-17 $\beta$ was very low (around 5 $\mathrm{pg} / \mathrm{mL}$ ) at the start of treatment. However, estradiol-17 $\beta$ concentration increased dramatically in all treatment groups during estrus. Estradiol-17 $\beta$ concentration during estrus was $45.6 \pm 2.0 \mathrm{pg} / \mathrm{mL}, \quad 44.8 \pm 2.6 \mathrm{pg} / \mathrm{mL}$ and $38.6 \pm 1.7 \mathrm{pg} / \mathrm{mL}$ in $\mathrm{PMSG} / \mathrm{hCG}$, PMSG and $\mathrm{GnRH}$ groups, respectively. 10 days post-mating, estradiol-17 $\beta$ decreased to $8.3 \pm 0.7 \mathrm{pg} / \mathrm{mL}$ in PMSG/hCG group and to $6.5 \pm 0.9 \mathrm{pg} / \mathrm{mL}$ in GnRH group. Meanwhile, estradiol$17 \beta$ concentration was higher in PMSG 10 days postmating compared with other groups (Table 3 ). 


\section{Discussion}

Anestrous mares characterized by absence of ovarian activity which may be due to lower content of pituitary LH, so anestrous mares will have small ovaries with only one or two small follicles $(<15 \mathrm{~mm})$ (Watson et al., 2002). These agree with the finding of the present study in which ultrasound examination of the ovaries did not show any large follicles. The absence of large follicles could be attributed to reduced GnRH synthesis and storage in the hypothalamus and decreased quantities of LH in the anterior pituitary (Hart et al., 1984). Therefore, it would be expected that administration of gonadotropins to anestrous mares would reinitiate ovarian activity.

The use of exogenous reproductive hormones and/or hormone analogues is important practice in equine reproduction. Most of the major hormones secreted by the hypothalamic-pituitary-ovarian axis are available as exogenous formulations that are used to regulate physiological and/or behavioural reproductive phenomena in mares.

eFSH may also be used for stimulating follicular development in anovulatory mares during the physiologic part of the breeding season. Niswender et al. (2004) demonstrated that administration of the commercial equine FSH twice daily to transitional mares resulted in 8 of 10 mares ovulating after approximately 5 days of injection. The use of Efsh treatment offers breeders a new safe and effective means of hastening the first ovulation of the year in transitional mares. In mares, FSH secretion, like that of $\mathrm{LH}$, is acutely driven by bursts of GnRH (Irvine et al., 1994). However, Gonadotropin Releasing Hormone $(\mathrm{GnRH})$ has a short half-life which limits its usefulness in mares; therefore, GnRH analogues such as Buserelin acetate are used. The ability of GnRH or its analogues to stimulate LH release has led to their use for ovulation induction in anovulatory mares using frequent injections (Bergfelt and Ginther, 1992).

One of the most widely and successfully used inducers of superovulation in many domestic species is the PMSG produced by the endometrial cups during days 35-120 of pregnancy in the mare (Tharasanit, 2011). The widespread use of PMSG has been exploitation of its FSH activity in induction of estrus, stimulation of the ovarian activity in anestrous animals and induction of superovulation (Murphy, 2012). The long half-life of PMSG confers the advantage of superovulation by means of a single injection, but the same trait also limits its usefulness, as it has the tendency to over stimulate the ovary, resulting in multiple, unovulated follicles and a yield of viable embryos that is highly variable (Bevers et al., 1989).
The results of the present study showed that a high dose of $\mathrm{PMGS} / \mathrm{hCG}$ combination induced follicular growth and ovulation in anestrous mares. This is in agreement with a study on Hokaido, Japan (Tsukada et al., 2008) which used 5000 IU of PMSG and 5000 IU of hCG to treat ovarian quiescence in mares. However, previous studies (Woods et al., 1982; Palmer et al., 1993) indicated that low dose PMSG did not affect follicle development in mares.

Levels of progesterone and estradiol reflect ovarian activity in which levels of both hormones are low in anestrous mares. Progesterone levels rises when a corpus luteum is formed after ovulation (Amer et al., 2008). Progesterone concentrations increase and reach maximal secretion by day 9 , which corresponds to the maximal growth of the CL. If the mare is not pregnant, the uterus secretes PGF $2 \alpha$ on approximately day 14, which causes the regression of the CL. Progesterone concentrations then decrease along with regression of the CL. Therefore, ovulation in mares can be confirmed by the rise of the progesterone and fall in estradiol levels during the pre- and post-ovulatory periods (Elmore et al., 1988).

In the present study, on the day 10 post-mating $37 \%$ of mares in the PMSG/hCG group and $30 \%$ in GnRH group had a high concentration of serum progesterone confirming that ovulation had occurred and a functional corpora lutea had been formed while in PMSG group, progesterone concentration was low indicating that ovulation and functional corpora lutea failed to establish. The failure in formation of a functional CL may be due to an inadequate LH surge at the time of the expected ovulation.

In the present study, although estradiol-17 concentration in the GnRH treated group is not significantly lower than other treatment groups, the signs of estrus is not so clear as in other treatment groups. Estradiol is responsible for estrus behavior and also estradiol is a key factor in generating a full LH surge in mares. It increases LH synthesis (Robinson et al., 1995) and may augment GnRH secretion. Administration of estradiol to ovariectomized mares increased LH concentrations (Aurich et al., 1995). However, in the present study, although estradiol concentration increased in PMSG group, there was no ovulation indicating that LH concentration may be not enough to make ovulation.

\section{Conclusion}

This study indicated that PMSG/hCG can be used to treat ovarian inactivity in mares. Also, the results showed that $\mathrm{GnRH}$ analogue buserelin acetate can be used. However, PMSG cannot be used alone for treatment of ovarian inactivity in mares due to failure of ovulation. 


\section{Author's Contributions}

Mohamed S. Medan: Design the research plan, clinical examination of mares, hormonal and statistical analysis, interpretation of the obtained data, writing and final approval for the article and mouse work.

Taher ALdaek: Design the research plan. Clinical examination of mares, treatment of the affected cases. Drafting the article.

\section{Ethics}

This article is original and contains unpublished materials. The corresponding author confirms that all of the other authors have read and approved the manuscript and no ethical issues involved.

\section{References}

Amer, H.A., G. Shawki and R. Ismail, 2008. Ovarian and endocrine changes during estrus and early pregnancy in Arabian mares. Slov. Vet. Res., 45: 25-32.

Aurich, C., 2001. Reproductive cycles of horses. Anim. Reprod. Sci. 124: 220-228. DOI: 10.1016/j.anireprosci.2011.02.005

Aurich, C., P.F. Daels, B.A. Ball and J.E. Aurich, 1995. Effects of gonadal steroids on the opioid regulation of LH and prolactin release in ovariectomized pony mares. J. Endocrin., 147: 195-202.

DOI: $10.1677 /$ joe. 0.1470195

Barbacini, S., G. Zavaglia, P. Gulden, V. Marchi and D. Necchi, 2000. Retrospective study on the efficacy of hCG in an equine artificial insemination program using frozen semen. Equine Vet. Educ., 2: 404-410.

Berezowski, C.J., K.L. Stitch, K.M. Wendt and D.J. Vest, 2004. Clinical comparison of 3 products available to hasten ovulation in cyclic mares. J. Equine Vet. Sci., 24: 231-233. DOI: 10.1016/j.jevs.2004.05.007

Bergfelt, D.R. and O.J. Ginther, 1992. Embryo loss following GnRH-induced ovulation in anovulatory mares. Theriogenology, 38: 33-43. DOI: 10.1016/0093-691X(92)90216-E

Bevers, M.M., S.J. Dieleman, H.T. Van Tol, D.M. Blankenstein and J. Van Den Broek, 1989. Changes in pulsatile secretion patterns of LH, FSH, progesterone androstenedione and estradiol in cows after superovulation with PMSG. J. Reprod. Fertil., 87: 745-754. DOI: $10.1530 /$ jrf.0.0870745

Crowell-Davis, S.L., 2007. Sexual behavior of mares. Horm. Behav., 52: 12-17. DOI: 10.1016/j.yhbeh.2007.03.020

Elmore, R.G., J.W. Shull, D.D. Varner and P.J. Meyers, 1988. Using progesterone assay kits to determine equine luteal function. Vet. Med., 83: 250-253.
Gastal, E.L., 2009. Recent advances and new concepts on follicle and endocrine dynamics during the equine periovulatory period. Anim. Reprod. Sci., 6: 144-158.

Hart, P.J., E.L. Squires, K.J. Imel and T.M. Nett, 1984. Seasonal variation in hypothalamic content of Gonadotropin-Releasing Hormone (GnRH), pituitary receptors for GnRH and pituitary content of luteinizing hormone and follicle-stimulating hormone in the mare. Biol. Reprod., 30: 1055-1062. DOI: 10.1095/biolreprod30.5.1055

Hyland, J.H., 1993. Uses of Gonadotrophin Releasing Hormone $(\mathrm{GnRH})$ and its analogues for advancing the breeding season in the mare. Anim. Reprod. Sci., 33: 195-207. DOI: 10.1016/0378-4320(93)90115-8

Irvine, C.H.G., P. Sutton, J.E. Turner and P.E. Mennick, 1990. Changes in plasma progesterone concentrations from days 17 to 42 of gestation in mares maintaining or losing pregnancy. Equine Vet. J., 22: 104-106.

DOI: 10.1111/j.2042-3306.1990.tb04219.x

Irvine, C.H.G., S.L. Alexander and J.E. Turner, 1994. Differential effects of graded doses of naloxone on the reproductive and adrenal axes in seasonally anestrous mares. Endocrine, 2: 913-919.

Murphy, B.D., 2012. Equine chorionic gonadotropin: An enigmatic but essential tool. Anim. Reprod., 9: 223-230.

Nagy, P., D. Guillaume and P. Daels, 2000. Seasonality in mares. Anim. Reprod. Sci., 60-61: 245-262. DOI: $10.1016 / \mathrm{S} 0378-4320(00) 00133-0$

Niswender, K.D., P.M. McCue and E.L. Squires, 2004. Effect of purified equine follicle-stimulating hormone on follicular development and ovulation in transitional mares. J. Equine Vet. Sci., 24: 37-39. DOI: 10.1016/j.jevs.2003.12.011

Palmer, E., G. Hajmeli and G. Duchamp, 1993. Gonadotrophin treatments increase ovulation rate but not embryo production from mares. Equine Vet. J., 15: 99-102.

Robinson, G., M.B. Porter, M.R. Peltier, B.C. Cleaver and T.A. Farmerie et al., 1995. Regulation of luteinizing hormone and a messenger ribonucleic acid by estradiol or gonadotropin-releasing hormone following pituitary stalk section in ovariectomized pony mares. Biol. Reprod. Monograph., 1: 373-383.

Samper, J.C., 2008. Induction of estrus and ovulation: Why some mares respond and others do not. Anim. Reprod. Sci. 70: 445-447.

SPSS, 2011. Statistical Package for the Social Sciences (SPSS). Chicago, USA.

Squires, E.L., 2008. Hormonal manipulation of the mare: A review. J. Equine Vet. Sci., 28: 627-634. DOI: $10.1016 /$ j.jevs.2008.10.010 
Stabenfeldt, G.H., P.F. Daels, C.J. Munro, H. Kindahl and J.P. Hughes et al., 1991. An estrogen conjugate immunoassay for monitoring pregnancy in the mare: Limitations of the assay between days 40 and 70 of gestation. J. Reprod. Fertil. Suppl., 44: 37-44. PMID: 1665516

Tharasanit, T., 2011. Control of follicle development and ovulation in mare: Principal and clinical aspects. Thai J. Vet. Med., 41: 55-57.

Tsukada, T., K. Sato, M. Moriyoshi, M. Koyago and Y. Sawamuka, 2008. Treatment with a high dose combination of PMSG/hCG preparation of mares clinically diagnosed with ovarian quiescence during the breeding season. J. Equine Sci., 19: 35-38.

DOI: $10.1294 /$ jes. 19.35
Watson, E.D., M. Heald, A. Tsigos, R. Leask and M. Steele et al., 2002. Plasma FSH, inhibin A and inhibin isoforms containing pro- and -alphaC during winter anoestrus, spring transition and the breeding season in mares. Reproduction, 123: 535-542. DOI: $10.1530 /$ rep.0.1230535

Woods, G.L., S.T. Scraba and O.J. Ginther, 1982. Prospects for induction of multiple ovulations and collection of multiple embryos in the mare. Theriogenology, 17: 61-72.

DOI: $10.1016 / 0093-691 X(82) 90116-9$ 